\title{
Influence of Online Media towards Passenger Car Purchasing in Tamilnadu [Impact and Problems Faced in using New Media]
}

\author{
T. S. Venkateswaran, J. Clement Sudhahar, S. Rajkumar
}

\begin{abstract}
In India, from the starting era of car purchasing is a hard matter in which the customer planning to buy a car has to go for detailed study how to, where to, when to and what to do before a car. It is full of personal survey of purchasing a car. A customer has to ask number of persons and their feedback to buy a car. The options are too less to decide. The customer visits numerous showrooms, take a look over car, the agent tries to influence the car he is selling. The rate of the car is also varies agent to agent. The customer felt very hard to decide which car to buy.Now online platform is a part of life from advertising, shopping with mails and information. These days users in the online have gone beyond their expectations. Social media is one of the speediest growing web applications in the twenty first century. A social network sites is a place where a user can create a profile and to build a personal network that connects him or her to other users. This study proposes how the Internet, new methods of digital advertising and social media supports the car marketing. Today the advertising has taken a new form in Internet era. The study proposes the new way of change in marketing of automakers. Also it reveals the user problems in using New Media of conserving passenger car purchasing decision.

Keywords: New Media Impacts, Passenger Car Market over New Media, Problems in using new media.
\end{abstract}

\section{IMPORTANCE OF THE STUDY}

Indian economy stands with the part of Automobile Industry emerging. The foreign companies have entered and trying to implant their brands in India as Automobile industry is growing day by day. The consumer has choice, huge information, confident and largely influenced by the internet in particularly new media. The automobile companies are considering note of this change and experimenting online marketing with the use of the online media. The steps had taken by the passenger car manufacturers and dealers to help in improving the level of satisfaction of their consumers via new media. A user friendly, efficient and knowledge based manufacturers and dealers' website also helps to gain buyer's confidence and increase their satisfaction. This step has created a strong and optimistic perception in purchase or maintenance of a car users in Tamilnadu.

\section{STATEMENT OF THE PROBLEM}

Online media is a choice to have a greater impact on the sales and will give higher level of sales. At this point, researcher were probed the following questions.

Revised Manuscript Received on October 10, 2019.

* Correspondence Author

Dr.T.S.Venkateswaran*, Placement Officer and Head, Department of MCA, K.S.Rangasamy College of Arts and Science (Autonomous)

Dr.J.Clement Sudhahar, Professor in Marketing and Research Head, Department of Management Studies, Karunya Deemed University

Mr.S.Rajkumar, Pursuing, PhD, Management, Bharathiar University, Coimbatore

(C) The Authors. Published by Blue Eyes Intelligence Engineering and Sciences Publication (BEIESP). This is an open access article under the CC BY-NC-ND license (http://creativecommons.org/licenses/by-nc-nd/4.0/)
- What extent the passenger car users aware and utilization behaviour of the new media?

- What extent the new media car advertisement has impacted the passenger car users?

- What are the problems faced by the passenger car users while using the new media car advertisement?

\section{OBJECTIVES OF THE STUDY}

1. To learn the functions of various new media websites and its effective advertisement.

2. To study the social-economic profile of the selected respondents.

3. Examine awareness and utilization behavior of New Media by the sample respondents in Tamilnadu.

4. To identify the buying and utilization behaviour of the Car and online advertisement among the sample respondents in Tamilnadu.

5. To evaluate the impact of new media advertisements, expectations and problems in watching online advertisements among the sample respondents in the study area.

\section{RESEARCH DESIGN}

Descriptive research is adopted by the researcher to study hence it describes the state it exists at present era. Both secondary and primary data are collected and implanted in this current study.

\section{SAMPLE SIZE}

Multi-stage sampling method has been used in this study for data collection. Area Sampling method was used for selecting the sample in the first stage. In this method, Tamilnadu has been selected in this research and selected 12 Corporations in Tamil Nadu were selected. The second stage is disproportionate random sampling method has been used. That means based on the proportion of the total passenger car users those purchased their car through new media advertisement in the respective cities, the sample passenger car users were decided to collect their opinion. The third stage is convenience sampling method that is based on the respondents' convenience, the passenger car users were selected for this research. The researcher collected the primary data relating to the personal details, awareness and utilization of new media, car buying and utilization behavior, attitude towards new media advertisement, impact of new media advertisement, expectation of viewers towards online advertisement, problems faced while viewing new media advertisement among the passenger car user in the selected cities of Tamil Nadu.

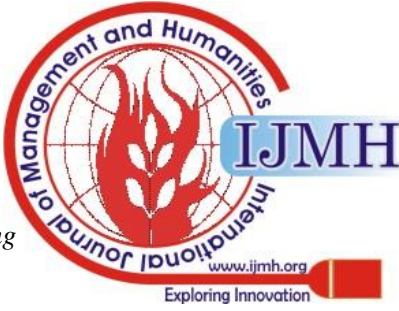


Table 1.1 [Distribution of Sample Size]

\begin{tabular}{|c|l|c|c|c|c|c|}
\hline S.No. & $\begin{array}{c}\text { District } \\
\text { Name }\end{array}$ & $\begin{array}{c}\text { Car } \\
\text { Users }\end{array}$ & $\begin{array}{c}\text { Sample } \\
\text { Collected }\end{array}$ & $\begin{array}{c}\text { Sample } \\
\text { Biased }\end{array}$ & $\begin{array}{c}\text { Final } \\
\text { Sample }\end{array}$ & $\begin{array}{c}\text { \% of population } \\
\text { distribution }\end{array}$ \\
\hline 1 & Chennai & 739759 & 471 & 22 & 449 & 48.1 \\
\hline 2 & Trichy & 77702 & 57 & 10 & 47 & 5.0 \\
\hline 3 & Madurai & 59412 & 43 & 7 & 36 & 3.9 \\
\hline 4 & Tirunelveli & 43328 & 35 & 9 & 26 & 2.8 \\
\hline 5 & Coimbatore & 275680 & 178 & 12 & 166 & 17.8 \\
\hline 6 & Salem & 70135 & 51 & 8 & 43 & 4.6 \\
\hline 7 & Erode & 58884 & 54 & 18 & 36 & 3.9 \\
\hline 8 & Tirupur & 93521 & 71 & 14 & 57 & 6.1 \\
\hline 9 & Thuthukudi & 27232 & 24 & 7 & 17 & 1.8 \\
\hline 10 & Vellore & 42637 & 34 & 8 & 26 & 2.7 \\
\hline 11 & Tanjore & 29447 & 29 & 11 & 18 & 1.9 \\
\hline 12 & Dindugal & 20804 & 19 & 6 & 13 & 1.4 \\
\hline & Total & $\mathbf{1 5 3 8 5 4 1}$ & $\mathbf{1 0 6 6}$ & $\mathbf{1 3 2}$ & $\mathbf{9 3 4}$ & $\mathbf{1 0 0 . 0}$ \\
\hline
\end{tabular}

Source : www.tn.gov.in/sta/stat1.html

\section{STATISTICAL TOOLS USED FOR ANALYSIS}

The long term use and the impact of online media advertising among the car users regarding on their location, gender, age, qualification, work, monthly family income, size of the family, frequency using of the online media in a day, period of aware of new media, type of car owned, frequency of using the car, period of the car used, fuel type, traveling average per day and type of car using were studied by percentages, mean, standard deviation, chi-square test, anova, correlation analysis, multiple regression analysis and ranking techniques. Also, factor analysis and SEM were used.

\section{REVIEW OF LITERATURE}

Venkateswaran and Clement Sudhahar, (2013) states that the consumer's perception to the purchase cars and listed the online media factors influenced the purchasing decision. From the study, it was founded that online media has the impact over the car buyers who were close to internet through computers, mobile phones, tablets etc., Maruti, Hyundai, Volkswagen and Kia had a major role in online media marketing through websites through commercial websites and pages they own.

Anand and Sujatha, (2014) states that the consumer's attitude towards multipurpose utility vehicles. The researchers claims the factors influence the buyers purchase sense of multipurpose utility vehicles. The study concludes from analysis and research survey, researcher identifies that all the respondents were having positive attitude about the multipurpose utility vehicle.

Werdich, (2015) found that the passenger car maintenance by companies and their local competitiveness. In research, influences from internal and external, has a change drivers and some of general changes in the companies strategies and their organization were analysed by identification. The influence of the development of technology strategies and the inclusion of innovations were remarkable parameters. The investigation results the influence of decision on the market participants and challenges. The study aims was the identification of influences on car maintenance and the current and future challenges with problems.

Darshan B.M (2018), the internet and online resources are vitally used for the business as well. The persistent growth of online and electronic commerce is highly attributed to the growing influence of the internet and social media. Along with the growth of online marketing strategies, there is an escalation of dependency on people which determine their tastes and purchasing decisions. The current trends indicate that online resources and social media are highly influential on people's purchasing decisions. The present study aimed towards investigating influence of the internet and social media resources on vehicle purchasing behavior. The study shows that internet and online resources are highly influential on the decision of purchasing a car. Socio-demographic characteristics of the participants are also prominent factors in the purchasing decision. The study implies the importance of maximizing the online and internet marketing strategies in the field of automotive industry.

\section{DATA ANALYSIS AND INTERPRETATION}

The statistical tools- Percentage, Mean, Standard Deviation, Chi-Square Test, Anova and Ranking Methods have been used appropriately.

1) Location of the respondents

\begin{tabular}{|c|l|c|c|}
\hline S-No & Location & $\begin{array}{c}\text { Respondent } \\
\text { Numbers }\end{array}$ & \% \\
\hline 1 & Chennai & 445 & 47.6 \\
\hline 2 & Coimbatore & 166 & 17.8 \\
\hline 3 & Madurai & 36 & 3.9 \\
\hline 4 & Tiruchirappalli & 47 & 5.0 \\
\hline 5 & Salem & 43 & 4.6 \\
\hline
\end{tabular}

Published By: Blue Eyes Intelligence Engineering 


\begin{tabular}{|c|l|c|c|}
\hline 6 & Tirunelveli & 26 & 2.8 \\
\hline 7 & Thoothukudi & 17 & 1.8 \\
\hline 8. & Tiruppur & 57 & 6.1 \\
\hline 9. & Erode & 36 & 3.9 \\
\hline 10. & Vellore & 26 & 2.8 \\
\hline 11. & Thanjavur & 18 & 1.9 \\
\hline 12. & Dindigul & 17 & 1.8 \\
\hline & TOTAL & $\mathbf{9 3 4}$ & $\mathbf{1 0 0 . 0}$ \\
\hline
\end{tabular}

6) Factors of New Media Advertisement will help at the time of purchasing

\begin{tabular}{|c|c|c|c|c|}
\hline $\begin{array}{l}\text { S- } \\
\text { No }\end{array}$ & Factors & Score & Mean & Ranking \\
\hline 1 & $\begin{array}{l}\text { Information on } \\
\text { product }\end{array}$ & 55917 & 59.9 & III \\
\hline 2 & Product Review & 54212 & 58.0 & $\mathrm{~V}$ \\
\hline 3 & $\begin{array}{l}\text { Product } \\
\text { Comparison }\end{array}$ & 55997 & 60.0 & II \\
\hline 4 & Price Analysis & 54014 & 57.8 & VI \\
\hline 5 & $\begin{array}{l}\text { 3-d Image of } \\
\text { Vehicles }\end{array}$ & 49043 & 52.5 & IX \\
\hline 6 & $\begin{array}{l}\text { No Intermediate } \\
\text { person to } \\
\text { influence }\end{array}$ & 56298 & 60.3 & I \\
\hline 7 & Own Decision & 54409 & 58.3 & IV \\
\hline 8 & $\begin{array}{l}\text { Advertisements } \\
\text { are catchy }\end{array}$ & 51595 & 55.2 & VII \\
\hline 9 & $\begin{array}{l}\text { Review of } \\
\text { previous } \\
\text { customers }\end{array}$ & 48349 & 51.8 & $X$ \\
\hline 10 & $\begin{array}{l}\text { Appeal / } \\
\text { Presentation } \\
\text { about car in } \\
\text { advertisement }\end{array}$ & 49487 & 53.0 & VIII \\
\hline
\end{tabular}

\section{2) Respondents By Gender}

\begin{tabular}{|c|c|c|c|}
\hline $\begin{array}{l}\text { S- } \\
\text { No }\end{array}$ & Sex & $\begin{array}{c}\text { Respondents } \\
\text { Number }\end{array}$ & $\%$ \\
\hline 1 & Male Respondents & 763 & 81.2 \\
\hline 2 & $\begin{array}{l}\text { Female } \\
\text { Respondents }\end{array}$ & 171 & 18.8 \\
\hline & TOTAL & 934 & 100.0 \\
\hline
\end{tabular}

\section{3) Purpose of Using Online}

\begin{tabular}{|c|l|c|c|}
\hline S.No. & Purpose & $\begin{array}{c}\text { No. of } \\
\text { Respondents }\end{array}$ & $\begin{array}{c}\text { Percentage } \\
\text { (Out of } \\
\text { 100) }\end{array}$ \\
\hline 1. & $\begin{array}{l}\text { Education } \\
\text { purpose }\end{array}$ & 210 & 20.2 \\
\hline 2. & Office purpose & 271 & 26.0 \\
\hline 3. & $\begin{array}{l}\text { Personal } \\
\text { purpose }\end{array}$ & 148 & 14.2 \\
\hline 4. & Entertainment & 185 & 17.8 \\
\hline 5. & Social contact & 154 & 14.8 \\
\hline 6. & Shopping & 73 & 7.0 \\
\hline
\end{tabular}

4) Aware of New Media

\begin{tabular}{|c|l|c|c|}
\hline S-No & Period & $\begin{array}{c}\text { Respondents } \\
\text { Numbers }\end{array}$ & \% \\
\hline 1 & 2 years below & 231 & 24.7 \\
\hline 2 & 2 to 5 Years & 365 & 39.2 \\
\hline 3 & 5 years above & 338 & 36.1 \\
\hline & TOTAL & $\mathbf{9 3 4}$ & $\mathbf{1 0 0 . 0}$ \\
\hline
\end{tabular}

5) Opinion of the respondents towards advertisements in new media as worthy

\begin{tabular}{|c|l|c|c|}
\hline S-No & Response & $\begin{array}{c}\text { Respondent } \\
\text { Numbers }\end{array}$ & $\mathbf{\%}$ \\
\hline 1 & Yes & 606 & 64.8 \\
\hline 2 & No & 328 & 35.2 \\
\hline & TOTAL & $\mathbf{9 3 4}$ & $\mathbf{1 0 0 . 0}$ \\
\hline
\end{tabular}

Retrieval Number: B0387104219/2019@BEIESP

\section{7) Problems faced in New Media}

To identify the problems encountered during watching online advertisements of respondents. To know, problems has been listed into 5 categories, it is difficult to be assured that the advertisement is reliable, it is difficult to be assured about advertisement on product performance, it is difficult to be assured that the product is reliable without touching it, online advertisements often make false claims and online advertisements make promises but keep up lesser. Identifying the important problem, Henry Garrett Ranking Technique was used and the problems encountered during watching online advertisements are

\begin{tabular}{|c|l|c|c|c|}
\hline S-No & \multicolumn{1}{|c|}{ Reasons } & Score & Mean & Ranking \\
\hline 1 & $\begin{array}{l}\text { Information on } \\
\text { product }\end{array}$ & 55917 & 59.9 & III \\
\hline 2 & Product Review & 54212 & 58 & V \\
\hline 3 & $\begin{array}{l}\text { Product } \\
\text { Comparison }\end{array}$ & 55997 & 60 & II \\
\hline 4 & Price Analysis & 54014 & 57.8 & VI \\
\hline 5 & $\begin{array}{l}\text { 3-d Image of } \\
\text { Vehicles }\end{array}$ & 49043 & 52.5 & IX \\
\hline 6 & $\begin{array}{l}\text { No Intermediate } \\
\text { person to influence }\end{array}$ & 56298 & 60.3 & I \\
\hline 7 & Own Decision & 54409 & 58.3 & IV \\
\hline 8 & $\begin{array}{l}\text { Advertisements } \\
\text { are catchy }\end{array}$ & 51595 & 55.2 & VII \\
\hline 9 & $\begin{array}{l}\text { Review of } \\
\text { previous } \\
\text { customers }\end{array}$ & 48349 & 51.8 & X \\
\hline & $\begin{array}{l}\text { Appeal / } \\
\text { Presentation about } \\
\text { car in } \\
\text { advertisement }\end{array}$ & 49487 & 53 & VIII \\
\hline
\end{tabular}

Published By:

Blue Eyes Intelligence Engineering

\& Sciences Publication

(C) Copyright: All rights reserved. 


\section{CONCLUSION}

The present study is mainly focused on impact of new media advertisement among the passenger car users in Tamilnadu. A reasonable proportion of the audience was not exposed to any new media advertising, although this is, arguably, also a characteristic of other media. The absence of some potential viewers could be offset by evidence of knowledge amongst those present during the new media advertising feature. However, the low levels of unprompted recall among the passenger car users, the vagueness with which passenger car users recalled some new media advertisements, and the varying proportions of passenger car users able to recall any details about the advertising content, raises more questions than it addresses about audio visual new media advertising and its effectiveness. Overall, it seems reasonable to conclude that, while facebook and twitter may fulfil a useful role as a support medium, media schedules in which it plays a dominant role in new media advertisement among the passenger car users.

\section{SCOPE FOR FUTURE RESEARCH}

- Each sub-element of these key aspects of future market has to be identified for further research. This study inculcates the challenge to marketers and researchers to understand the market.

- This study was conducted in Tamilnadu. Comprehensive studies can be conducted at National level or International level by increasing the size of the sample.

- Comparative study of impact of new media advertisements on two wheelers and four wheelers in Tamilnadu.

\section{REFERENCES}

\section{BOOKS}

1. Naresh K.Malhotra, (2019). Marketing Research: An Applied Orientation, 7th Edition, Pearson Publications.

2. Heidi Taylor, (2017). B2B Marketing Strategy: Differentiate, Develop and Deliver Lasting Customer Engagement. First Edition, Kogan Page.

3. Kaushik Mukerjee,(2007). Customer Relationship Management: A Strategic Approach to Marketing. Kindle Edition, Fourth, PHI

4. Dr. F.C. Sharma, (2017). Principles of Marketing. Second Edition, SBPD Publications.

5. Simon Kingsnorth (2019). Digital Marketing Strategy: An Integrated Approach to Online Marketing, Second Edition Kogan Page, New Delhi.

\section{WEBSITES}

1. www.marketingworld.com

2. www.AdAge.com

3. www.Semrush.com

4. www.DirectMarketing.com

5. www.DigiDay.com

\section{AUTHORS PROFILE}

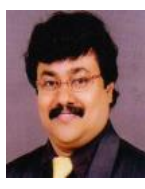

Dr. T.S.Venkateswaran M.Sc, M.Phil, M.B.A, M.Phil, Ph.D, working as Placement Officer and Head, Department of MCA, K.S.Rangasamy College of Arts and Science (Autonomous) has 18 years of Teaching experience with sound Research holdings such as 3 Books Publications, 8 International Articles, 29 National Level Conference Paper Presentations and acted as Resource Person in Colleges and Universities in Tamilnadu.

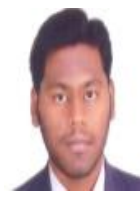

Dr. J.Clement Sudhahar, MBA, PhD, Professor in Marketing and Research Head, Department of Management Studies, Karunya Deemed University morethan 24 years of Teaching Experience. He has published 71 Research

Publications, 8 Book Publications, 5 Educational Awards, 2 Research Awards and produced 7 PhD Candidates.

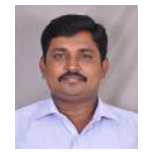

Mr. S.Rajkumar, M.B.A, M.Phil, (Ph.D), Excel Business School, Komaraplayam has published 2 International Publications, 18 National Paper Presentations and also attended morethan 10 Faculty Development Programmes. He is pursuing his $\mathrm{PhD}$ in Management at Bharathiar University, Coimbatore under the guidance of Dr.J.Clement Sudhahar. 